\title{
Teachers' planning and preparation of teaching resources and materials in the implementation of Form 4 Physical Education curriculum for physical fitness strand
}

\section{Syed Kamaruzaman bin SYED ALI, Muhammad Akbar bin ZAHIDI}

Faculty of Education, Universty of Malaya, Malaysia.

Address correspondence to S. K. Syed Ali, syed@um.edu.my

\begin{abstract}
This study was conducted to identify the level of teachers' preparation of teaching resources and materials in the implementtaion of Form 4 Physical Education for physical fitness strand. As a descriptive study, the location was selected in the district of Gombak, Selangor. Respondents who were involved in this study consisted of 50 teachers with Physical Education option and are teaching Form 4 students. The instrument employed to collect data was in the form of structured checklist and interviews. The findings of this study showed that the preparation level of Physical Education teachers towards the teaching resources and materials such as newspaper articles, magazines, articles / journals, Physical Education /Sports Science reference books and materials from the Physical Education panel files were moderate. Apart from that, the studied Physical Education teachers have also made preparation by utilizing diagrams and charts adapted from the Form 4 Physical Education textbook. The overall mean for the teaching resources and materials is 3.70 with a standard deviation of .84 . The findings also showed that the preparation level of Physical Education teachers towards teaching resources and materials was at high level. The teaching resources and materials must be prepared properly so that Physical Education teachers can use them effectively during the teaching and learning process.
\end{abstract}

Keywords: Teachers' planning, teaching resources and material, physical education.

\section{INTRODUCTION}

Teaching resources and materials are some of the factors that can assist in the implementation of effective teaching and learning. Hence, according to Oliva (11), teaching resources and materials are vital components that needs to be included in lesson plans. Teaching materials can be employed to stimulate learning, maintain interests, enhance variety in lessons and portray relationships between subjects (18).

There are many teaching resources and materials that can be applied in lessons. For instance, the textbook which is prepared by the school. Textbook is an example of main resource material for teaching and learning that can be used in schools (14). Thus, the Form 4 Physical Education textbooks which are supplied by the schools for students can be used by teachers as the main reference material in the process of teaching and learning of Physical Education for physical fitness strand. Besides, the textbook can also be applied by the teachers in planning their teaching. According to Khalid (7), the use of textbooks as basic material in planning teachings has been employed by most teachers in schools. A research conducted by Rosly et al. (13) revealed that $36.3 \%$ of trainee teachers frequently use textbooks during teaching and learning sessions. Although the percentage of use did not achieve $50 \%$ or more, but it proved that the use of textbooks as teaching resource and material still relevant among teachers in schools.

Apart from that, diagrams and charts that function as illustrated materials in textbooks are the dominant aspects to be used by teachers in teaching (7). Demonstration through illustrations along with explanations can increase the learning of teaching materials (5). In the Form 4 Physical Education textbook, there are various diagrams and charts which are related with fitness activities. Charts or diagrams together with explanaitons will help students to learn better (5). Also, the findings from a study by Tina et al. (21) revealed that the preparation of reference materials including textbooks are one of the factors that can influence the effectiveness of In-Service Course programme implementation strategy. Therefore, the Form 4 Physical Education textbook must be adequately provided to all students so that it can assist physical 
education teachers to implement the curriculum for physical fitness strand satisfactorily.

Aside from textbooks, audio visual tools (AVT), tasksheets, videos, handycams, data management software, teaching software (CD / DVD or Digital Versatile Disk) can enhance students' involvements in teaching processes (16). The teaching and learning process of Physical Education will become better when there are interactions from various variables. One of the variables is the resource aspect (20). According to Shahabuddin et al. (15), interferences in classrooms can be avoided by visualizing the teaching with appealing teaching resources or materials. Therefore, Physical Education teachers must plan to prepare resources or materials that are appropriate for the teachings that are related with fitness. All the materials that will be used must be prepared and collected adequately before starting any teaching (18).

The implementation strategy of national secondary school educational policy has stressed on the usage of teaching aid materials (Educational Policy Planning and Research Division, 1999). Thus, with the availability of teaching aid materials, teachers will be able to prepare appropriate activities when implementing the teaching and learning of Form 4 Physical Education for the fitness strand. Also, selection and adaptation of the teaching materials must be made according to the students' development level (19).

Next, the teaching materials must be synchronized with the objectives and contents of the lesson to be delivered (22) so that teachers will be able to apply all kinds of teaching materials related with each lesson topic (11). Shahabuddin et al. (15) have recommended a few matters to be considered when selecting teaching resources, in which the resources must be suitable with the students' age level and their abilities, contain information (pictures and writings) that are clear and interesting, contain appropriate colors and sizes, contain adequate level of language, bias-free (such as gender and racial) and can be used by students.

Based on the content in the Form 4 Physical Education textbook, there are various resources and materials that can be employed for teaching. For example health magazines, journals, educational television shows, diagrams related with heart structure and respiratory system, sample of preexercise levels table and target zones for cardiovascular endurance, diagram of exercise activities or games to enhance muscular endurance, comparison table between muscular strengths and muscular endurance exercises, table of upper body muscular strength exercise, table of upper body strength without weightlifting, table of football team weightlifting exercise, and diagrams of activities or games to increase muscular strengths (17). Besides that, numerous forms, distributable materials and newspaper articles can also be used in the teaching and learning process (12).

Video (interactive) is also one of the teaching resources and materials that can be utilized by teachers in implementing the teaching and learning of Form 4 Physical Education for the fitness strand. A study conducted towards the Interactive Multimedia Module found that most students are more interested towards varieties of medias such as texts, audios and visuals (1). The same was found from a study by Mohamad (16) towards the contents and presentation elements of the interactive multimedia module. The results from these studies showed that the contents of interactive multimedia module has assisted to ease up students' learning process. Interactive compact discs containing teaching materials are also helpful in the teaching and learning process (4).

Internet is also one of the methods to obtain information to assist in the teaching and learning process of Form 4 Physical Education for fitness strand. The internet is capable of preparing reference materials as a whole (3). Teachers or students can use the internet as preparation before implementing Form 4 Physical Education for fitness strand. Mohd Izal (9) suggested that students and educators to use internet knowledge and searches. For teachers, they can use the email to share about teaching techniques and lesson plans with teachers from other schools through the internet (10). Besides, teachers and students can use the search engines to gather information or knowledge which are related with the lesson contents. According to Mohnsen (10), the most popular search engine are yahoo.com (www.yahoo.com), altavista.com (www.altavista.com) and google.com (www.google.com). From search engines, Physical Education teachers or students can just type and fill up the information related with the fitness topic in the provided space and then click 'search'. All the information or notes related with fitness will be listed, where they can select anything relevant. 
For students, they can also use the educational portals. Educational portals are often in the form of websites on the internet that can be utilized as a place to obtain information and learning materials such as lecture notes, tutorials, tasks and lab reports (8). Findings from a study by Mohd Izal (9) denotes that the use of portals is interesting and effective in learning, according to respondents' perceptions.

Based on the discussed theories, it was proven that the aspects of teaching resources and materials are vital and must be prepared by each Physical Education teachers before implementing any teaching and learning. Hence, this study was conducted to examine the extent to which Physical Education teachers in secondary schools in Gombak District, Selangor have made preparations with regard to teaching resources and materials before they implemented the teaching and learning process.

\section{MATERIAL \& METHODS}

This study employed descriptive framework because it intends to examine the extent to which Physical Education teachers in secondary schools in Gombak District, Selangor have made preparations with regard to teaching resources and materials in the implementation of Form 4 Physical Education for the fitness strand. 52 research instruments (Interview-Structured Questionnaire) were distributed to collect data. From the 52, 50 respondents have fully completed them while the other 2 respondents did not complete them thus were rejected as samples. The total number of instruments therefore made up $93 \%$ of the total population as research samples. The percentage of samples was enough to represent the research population in Gombak District. As according to Gay (1981), the minimum number of samples required for a descriptive study is at least $10 \%$ of the whole research population.

\section{RESULTS}

Table 1 showed the mean, standard deviation and Physical Education teachers' level of preparation towards the elements within teaching resources and materials.

Based on Table 1, it was found that the preparation level of Physical Education teachers towards the teaching resources and materials in relation to the element of internet was high $(\mathrm{M}=3.87$; $\mathrm{SD}=.86$ ). The preparation level in relation to the Form 4 Physical Education textbook was also high $(\mathrm{M}=3.90 ; \mathrm{SD}=.80)$.

Meanwhile, the level of preparation of the teaching resources and materials from newspaper articles $(\mathrm{M}=3.59 ; \quad \mathrm{SD}=.88)$, magazines $(\mathrm{M}=3.45$; $\mathrm{SD}=.77)$, articles of journals $(\mathrm{M}=2.45 ; \mathrm{SD}=.66)$, Physical Education or Sports Science reference books $(M=2.97 ; S D=1.07)$, and resources from the Physical Education panel files $(\mathrm{M}=3.00$; $\mathrm{SD}=1.33)$ were recorded at moderate level. From the seven elements, it was found that Physical Education teachers have the tendency to make preparations by using teaching resources and materials from the internet and Form 4 Physical Education books as compared to the others.

\begin{tabular}{|c|c|c|c|}
\hline Teaching Resources and Materials & $\mathrm{M}$ & $\mathrm{SD}$ & Level \\
\hline i. Internet & 3.87 & .86 & High \\
\hline ii. Newspaper Articles & 3.59 & .88 & Moderate \\
\hline iii. Magazines & 3.45 & .77 & Moderate \\
\hline iv. Articles / Journals & 2.45 & .66 & Moderate \\
\hline v. Physical Education / Sports Science Reference Books & 2.97 & 1.07 & Moderate \\
\hline vi. Physical Education Panel Files & 3.00 & 1.33 & Moderate \\
\hline vii. Form 4 Physical Education Textbook & 3.90 & .80 & High \\
\hline
\end{tabular}

M: Mean, SD: Standard Deviation

\section{DISCUSSION}

This discussion is related with the preparation of Physical Education teachers towards the teaching resources and materials. The process of teaching and learning requires the best preparation by a teacher (6). Hence, teaching resources and materials must be appropriately prepared by teachers before they conduct the teaching and learning process in implementing the Form 4 Physical Education curriculum for the physical fitness strand.

Based on the findings from this study, the teaching resources and materials prepared by Physical Education teachers consisted those from the internet, newspaper articles, articles / journals, 
Physical Education / Sports Science reference books, and materials from the Physical Education panel as well as the Form 4 Physical Education textbook. It was further found that the internet and the Form 4 Physical Education textbook were the resources and materials that are mostly prepared by teachers as compared to others. This is possibly due to the fact that the internet and the Form 4 Physical Education textbook are materials that are easily accessible and applied. In overall, it was found that the preparation of teaching resources and materials by Physical Education teachers were at high level $(\mathrm{M}=3.70$; $\mathrm{SD}=.84$ ).

These findings denote that the preparation in the aspect of teaching resources and materials is a vital matter. The Physical Education teachers in Gombak District have been making satisfactory preparations with regard to teahcing resources and materials in the implementation of the Form 4 Physical Education curriculum for the physical fitness strand. The findings supported the view from Oliva (11) who stated that teaching resources and materials are important components and must be included in teachers' lesson plans. Siti Aishah (17) also recommended that the materials to be used in teachings must be properly prepared and collected before any teaching begins.

In conclusion; teaching resources and materials are important components that must be initially prepared by Physical Education teachers before they implement teaching and learning process. The teaching resources and materials that can be used in the implementation of Form 4 Physical Education for fitness strand include the internet, newspaper articles, and journals. Apart from that, Physical Education teachers can also employ the Physical Education of Sports Science reference books and textbooks as teaching resource and material. As the same time, every school is also equipped with files which contain Physical Education teaching materials. Therefore, Physical Education teachers may as well use the materials from the files. In overall, Physical Education teachers should have no problem in preparing teaching resources and materials.

\section{REFERENCES}

1. Abdul Rahim MS. Pengajaran dan pembelajaran: Pembinaan modul pembelajaran reka bentuk struktur kayu secara interaktif. Dalam koleksi abstrak penyelidikan pengajian siswazah. Kolej Universiti Teknologi Tun Hussein Onn, 2006, 28.
2. Bahagian Perancangan dan Penyelidikan Dasar Pendidikan. Strategi pelaksanaan dasar pendidikan kebangsaan sekolah menengah. Kuala Lumpur: Kementerian Pelajaran Malaysia, 1999.

3. Internet Dalam Penggunaan Pendidikan. Retrieved September $\quad 10, \quad 2010 \quad$ from http://www.ppdbesut.net/nuke/edu/idp.pdf, 2010.

4. Jahuri J. Penghasilan modul pembelajaran CD interaktif bagi mata pelajaran instrumentasi. Dalam koleksi abstrak penyelidikan pengajian siswazah, Kolej Universiti Teknologi Tun Hussein Onn, 2006, 108.

5. Jamet E, Gavota M, Quaireau C. Attention guiding in multimedia learning. Learning and instruction, 2008; 18: 135 145.

6. Ke arah Amalan Pengajaran Guru yang Berkesan. Retrieved November 3, 2011 from http://www.scribd.com/doc/5032641, 2011.

7. Khalid P. Penggunaan buku teks dalam pengajaran peringkat menengah. Laporan Penyelidikan, Tidak diterbitkan, Fakulti Pendidikan, Universiti Malaya, 1999.

8. Khamis F. Kepentingan portal pendidikan bagi pengajaran dan pembelajaran elektronik di kalangan pelajar sarjana muda kejuruteraan elektrik di Kolej Universiti Teknologi Tun Hussein Onn. Dalam koleksi abstrak penyelidikan pengajian siswazah. Kolej Universiti Teknologi Tun Hussein Onn. 2006, 34 .

9. Mohd Izal J. Portal web jarum sebagai mekanisme tambahan dalam pembelajaran seni reka fesyen. Dalam koleksi abstrak penyelidikan pengajian siswazah, Kolej Universiti Teknologi Tun Hussein Onn, 2006, 46.

10. Mohnsen BS. Teaching middle school physical education. $2^{\text {nd }}$ ed.USA: Human Kinetics, 2003.

11. Oliva PF. Developing the curriculum. $6^{\text {th }}$ edition. Boston: Pearson, 2005.

12. Rahmad Sukor AS, Shahril J. Peranan kepimpinan guru dalam mempengaruhi iklim bilik darjah. Masalah Pendidikan, Fakulti Pendidikan, Universiti Malaya, 2005; 28: 117-129.

13. Rosly I, Sim AH, Razali LN. Kekerapan penggunaan media pengajaran di kalangan guru pelatih semester 6 semasa praktikum. Jurnal Penyelidikan Maktab Perguruan Sultan Abdul Halim (MPSAH), 2001, 38-54.

14. Sahban. Peranan buku teks dalam pendidikan sains dan matematik di sekolah. Prosiding International Conference on Science \& Mathematics Education, 2003, 14-16.

15. Shahabuddin H, Rohizani Y, Mohd ZA. Pedagogi. strategi dan teknik mengajar dengan berkesan. Shah Alam: PTS, 2003.

16. Shahril M. Penghasilan modul pembelajaran interaktif berkomsepkan multimedia bagi mata pelajaran Autocard (3D Modelling). Dalam koleksi abstrak penyelidikan pengajian siswazah, Kolej Universiti Teknologi Tun Hussein Onn, 2006, 45.

17. Shamsudin MS, Shahrizad Y, Mohd SOF. Kurikulum Bersepadu Sekolah Menengah. Pendidikan Jasmani dan Pendidikan Kesihatan Tingkatan 4. Selangor: Dewan Bahasa dan Pustaka, 2002. 
18. Siti AME. Mengajar secara efektif. Kuala Lumpur: ITNMB, 2007.

19. Siti HO, Mazlen A, Norasmah O, Zamri M. Strategi guru novis dalam pengajaran dan pembelajaran. Dalam Norasmah Othman, Zamri Mahamod, Mohammed Sani (Eds). Kesediaan profesionalisme guru novis: Cadangan model latihan, 2006.

20. Suomi J, Collier D, Brown L. Factors affecting the social experiences of students in elementary physical education classes. Journal of Teaching in Physical Education, 2003; 22: 186-202.

21. Tina LSK, Mohd NB, Mohd AMD, Baharudin Y, Mohd JZ. Penilaian terhadap kesesuaian dan keberkesanan kursus dalam perkhidmatan. Jurnal Penyelidikan Guru, 2007; 3: 85101.

22. Yahya AS. Siri pentadbiran pendidikan. Mengurus sekolah. Pahang: PTS Publications, 2003. 